\title{
Potential impacts of changing climate on nature-based tourism: A case study of South Africa's national parks
}

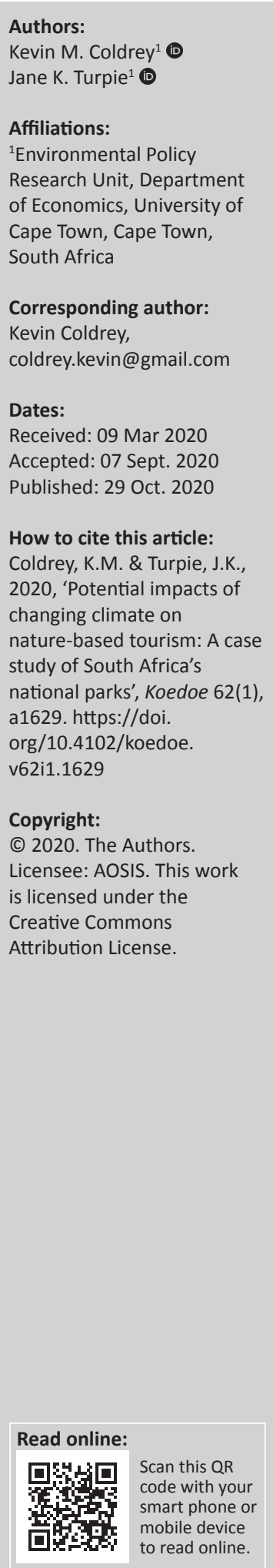

Climate change could potential have significant impacts on the global tourism industry through changes in accessibility, comfort levels, and geographic or seasonal changes to attractions. Global and regional studies based on climate indices suggest that there will be global shifts in tourism, with many of the currently warmer areas potentially experiencing decreases in tourism. These include much of the global south, where nature-based tourism is both an important contributor to economic output and believed to be vulnerable to climate change. Protected areas form the core of nature-based tourism in many developing countries and are also directly or indirectly dependent on this tourism for their funding. However, comparatively little empirical work has been done on protected area tourism, particularly in developing countries. We modelled the relationship between occupancy and mean monthly temperature at each of South Africa's 19 national parks and estimated the potential change in demand as a result of climate change. We found significant quadratic or linear relationships between occupancy and temperature for all parks. A single network-wide model could not capture all the location-specific temperature and tourism demand dynamics occurring at individual parks. The temperature models explained over $50 \%$ of the variance in historical occupancy for 17 parks, suggesting that climate change may have a significant impact on the timing and magnitude of demand across the network. Based on projected future temperatures, visitation rates across all parks could decline by nearly $4 \%$ by 2050 , with most of the decline in Kruger National Park, which has the lion's share of visitors.

Conservation implications: The results are of concern given that tourism proceeds generated by Kruger National Park are used to subsidise the operating budgets of the entire park system, which would put the capacity for conservation activities at risk, suggesting that measures to alleviate climate discomfort to tourists should be explored by management.

Keyword: climate change; tourism; protected areas; statistical analysis; national parks.

\section{Introduction}

Climate change has the potential to have significant impacts on the global tourism industry through changes in accessibility and comfort levels, as well as geographic or seasonal changes to attractions (Rosselló-Nadal 2014; Scott, Gössling \& Hall 2012). Global and regional studies based on climate indices and data suggest that there will be global shifts in tourism, with an improvement in conditions in many temperate areas and a deterioration in conditions in many subtropical and tropical areas (Bigano, Hamilton \& Tol 2007; Rosselló \& Santana 2012; Tol \& Walsh 2012). Indications are that tourism may decline in much of the Global South. This is of particular concern, not only because tourism is a significant source of foreign exchange earnings in developing countries (Scott et al. 2012), but also because of the global importance of biodiversity conservation in these countries and the direct and indirect reliance of conservation on nature-based tourism. However, comparatively little empirical work has been done on nature-based or protected area tourism, particularly in developing countries.

Protected areas form the core of both biodiversity conservation and nature-based tourism throughout Africa. In South Africa, the national parks are semi-autonomous and derive much of their operating budget from tourism revenues. In addition to the threats of climate change on park biodiversity and infrastructure, climate change may also have an impact on tourism numbers and revenues as a result of extreme events such as drought and changes in expected daily maximum temperatures. Indeed, nature-based tourism has been identified as being particularly vulnerable to climate change, and this has been verified in several recent studies undertaken in 
the region (Dube \& Nhamo 2018, 2019, 2020; Dube et al. 2018; MacFadyen et al. 2019; Mushawemhuka, Rogerson \& Saarinen 2018; Sutherland, Ndlovu \& Pérez-Rodríguez 2018). This study extends the existing literature by undertaking an empirical analysis of the sensitivity of park tourism to temperature, based on historical data.

South Africa has a large nature-based tourism industry, a well-managed national park system and reliable historic tourism data. Furthermore, substantial and varying climate change is predicted for South Africa (Davis-Reddy \& Vincent 2017), which has the potential to alter demand for this industry (Pandy \& Rogerson 2018; Rogerson 2016). A study by Van Wilgen et al. (2016) on the change in climate already experienced in South Africa's national parks over the past few decades indicates that significant temperature increases have already been experienced in most parks. The observed temperature changes over the last 20-50 years have, in several instances, already reached those predicted for near future scenarios. These changes in temperature may have already influenced the timing of park visitation in the hotter, non-coastal areas of the country, where peaks have shifted to the cooler winter months. This study uses South Africa's national parks as a case study to explore the influence of climate on tourism demand by using empirical models, so that the potential unmitigated impact of climate change on tourism demand can be estimated. Following Fisichelli et al.'s (2015) study of parks in the United States of America, we analysed historical monthly visitation data for parks in relation to mean monthly air temperature data obtained from the Climatic Research Unit (CRU). Our study shows that impacts are positive for some more temperate parks, but that overall visitation rates are likely to decrease in the absence of mitigation.

\section{Literature review}

Tourism is a highly climate-dependent industry (Amelung, Nicholls \& Viner 2007; Hamilton, Maddison \& Tol 2005), which can either act to compel tourists to leave their own countries in search of more favourable locations, or it can compel tourists to seek out locations with climates that lend themselves to specific tourism attractions, such as snowfall for winter sports tourism or temperate weather for coastal and nature-based tourism (Rosselló-Nadal 2014; Scott et al. 2012). Apart from providing the means for tourists to partake in specific activities, a pleasant, comfortable climate has the ability to draw tourists as much as other more catalogued destination attributes (De Freitas 2003; Kozak 2002). In fact, many regions rely on their climate as the natural resource that draws tourists (Scott et al. 2006). It is important to note that tourists' choices are different from those of recreationists, in that the latter can react to immediate weather, whereas tourism decisions are planned more in advance (Amelung et al. 2007). Thus, tourism will be a function of expected conditions for a locality in any given month. Furthermore, climate is one of the factors affecting the seasonality of tourism, along with other natural and institutional factors such as the timing of holidays. Thus, climate change is likely to impact the seasonality of tourism as well as overall tourism arrivals (Koenig \& Bischoff 2004).

Although earlier models of tourism demand seldom considered climate (Pike 2002), the impact of climate on tourism was first studied in the 1980s and became a dominant theme in the tourism literature by the 2000s (Hamilton \& Tol 2007; Scott et al. 2012). Studies on the potential impacts of climate change on tourism date back to the 1990s, when Abegg and Koenig (1997) predicted a reduction in the reliability of snow for Swiss ski areas. Studies have used a range of qualitative and statistical approaches to consider the potential impacts of changes in climate and/or its impacts on physical conditions for tourism (Moore 2010; Rosselló-Nadal 2014). Irrespective of the approach, studies have consistently found that there is a quadratic (inverted U) relationship between tourism and climate (Hamilton et al. 2005; RossellóNadal 2014). In other words, preferences tend to be for moderate or 'comfortable' conditions (Lise \& Tol 2002; Mieczkowski 1985), and climate change could positively or negatively impact on tourism demand.

Many studies have made use of a composite index of climate suitability, notably Mieczkowski's (1985) tourism climate index (TCI), which is a weighted index composed of seven normalised variables. This index has been used to assess potential changes in tourism demand in various parts of the world (e.g. Amelung \& Viner 2006; Amelung et al. 2007; Perch-Nielsen, Amelung \& Knutti 2010; Roshan, Yousefi \& Fitchett 2015; Scott \& McBoyle 2001; Scott et al. 2016). For example, by using the TCI, Amelung et al. (2007) explored the potential impacts of climate change on tourism at a global scale. They calculated the TCI for each grid cell across the land surface of the earth for different decades in the past and future and classified 'good' months as those with a TCI greater than 70 . They found that although some locations are likely to experience substantial increases in attractiveness, others may become significantly less appealing. Indeed, these studies have consistently shown that temperate regions tend to become more attractive, whereas tropical and subtropical areas tend to become less attractive. However, this approach is criticised because ideal conditions might vary across destinations (Moore 2010; Scott, Gossling \& Freitas 2007), as well as for tourists from different origins (Lin \& Matzarakis 2008). These rather qualitative approaches, such as those predicting negative impacts of heat waves in Mediterranean countries, also came under criticism for being unable to define what conditions would be too severe for tourists (Scott et al. 2012).

Predicting future changes is arguably best dealt with through statistical and econometric approaches that use historical arrivals data. Such approaches have used time series, crosssectional and panel data analyses (Maddison 2001; Moore 2010; Rosselló-Nadal 2014). Although time series and crosssectional approaches are vulnerable to model specification and other biases, panel data approaches have the advantage of controlling for fixed or random effects. Moore (2010) incorporated the TCI as a variable in a dynamic panel 
approach with monthly observations over a number of years, to predict the effects of climate change for Caribbean destinations. Their rigorous analysis suggested reductions in tourism arrivals by $1 \%-5 \%$ under a $2071-2100$ climate. Nevertheless, use of the TCI is still questionable as it has not been tested empirically (Scott et al. 2012), and use of a weighted index still implies a constant weighting of temperature variables within the index across all tourist types and destinations. Avoiding this problem, global- and regional-scale tourism impacts have also been modelled by using simple climate variables such as temperature and/or precipitation (Hamilton \& Tol 2007; Rosselló \& Santana 2012; Tol \& Walsh 2012). For example, using pooled ordinary least squares (OLS) regression and controlling for a range of factors that attract or deter tourists, such as coastline, poverty and heritage, Tol and Walsh (2012) found that tourists were attracted by intermediate precipitation and temperatures, with those from warmer countries being more sensitive to climate. Few, if any, statistical or econometric studies have used the range of climate variables incorporated into Mieczkowski's (1985) TCI. This may be partly because of the difficulty of obtaining suitable data to properly populate the TCI, as was found in South Africa (Fitchett, Robinson \& Hoogendoorn 2017).

Studies that have focussed on the global tourism industry at the macro-country level have indicated that climate change could lead to a gradual shift of tourists towards higher latitudes and that climate change would lead to tourists from temperate nations altering their travel patterns to take advantage of new climatic opportunities closer to home. This trend is likely to be exacerbated by the rising aversion to long-haul flights owing to tourists' considerations of their carbon footprints. This shift in tourism destinations globally would be at the expense of tropical and sub-tropical destinations (Bigano, Hamilton \& Tol 2007; Hamilton et al. 2005). However, such analyses may overlook the niche climates within countries that attract tourists. With climate change predicted to vary spatially across countries (Chown 2010; Collier, Conway \& Venables 2008), changes in climate at a more micro-scale are likely to alter the distribution or seasonality of tourism demand within countries.

Although many of the well-studied Northern Hemisphere destinations expect to see moderate changes or increases because of warmer temperatures, destinations that are already relatively warm and have relatively good TCI indices, such as South Africa (Fitchett et al. 2017), may be expected to experience decreased demand because of increased heat discomfort as well as other climate change effects such as increased drought, habitat and wildlife changes and poverty. Impacts on tourism are also likely to have a disproportionately higher significance in the Global South (Rogerson 2016). Indeed, given the severity of projected climate change in southern Africa, this region is considered one of the most vulnerable in the world (Hoogendoorn \& Rogerson 2015; Pandy 2017; Rogerson 2016). In terms of the risks to the tourism industry, nature-based tourism is considered particularly vulnerable (Pandy \& Rogerson 2018; Preston-
Whyte \& Watson 2005; Steyn \& Spencer 2012). Apart from the expected changes in comfort levels for visitors, nature-based tourism destinations are vulnerable to changes in the species and ecosystems that attract those visitors (Belle et al. 2016; Dunlop \& Brown 2008; Lemieux et al. 2010; Van Der Merwe \& Saayman 2008).

Changing demand for nature-based tourism will add to the range of threats that face protected areas under climate change. Protected area systems are often directly dependent on revenues from tourism or on government support, which is partly leveraged because of their contribution to national tourism. As for tourism in general, the impacts of climate change on demand for park visitation could be very different in different parts of the world. In one of the first studies focussing on climate change impacts on protected area tourism, Jones and Scott (2006) used OLS regressions between visitation and climate variables (temperature and precipitation) to predict an increase in visitation to Canadian protected areas under future climate conditions. Fisichelli et al. (2015) modelled historical monthly visitation data for parks in the United States of America in relation to mean monthly air temperature by using generalised linear models. Their models (for the park system as a whole as well as for individual parks) also predicted an increase in future visitation as a result of climate change, particularly in the low season. In their study, the response variable was the proportion of the park's annual visits occurring in a month (to standardise across parks with different overall rates of visitation), and the explanatory variables were mean monthly temperature and park name.

In southern Africa, on the other hand, climate change is a serious concern for park tourism (Dube \& Nhamo 2020; MacFadyen et al. 2019; Sutherland et al. 2018). Tourists to South Africa are potentially sensitive to high temperatures (Giddy, Fitchett \& Hoogendoorn 2017), and in Kruger National Park the annual average maximum temperature has increased from around $29^{\circ} \mathrm{C}$ to over $31^{\circ} \mathrm{C}$ since the 1970 s (Dube \& Nhamo 2020). A series of mixed-methods studies involving semi-structured interviews have shown that rising temperatures and drought have already impacted on tourism experiences in flagship parks of the region such as Kruger National Park, Victoria Falls, the Okavango Delta and the Hwange National Park (Dube \& Nhamo 2018, 2019; Dube et al. 2018; Mushawemhuka et al. 2018), as well as in private nature reserves (Smith \& Fitchett 2020). These conclusions are supported by empirical evidence of the negative impact of drought on numbers of visitors in Kruger National Park (Mathivha, Tshipala \& Nkuna 2017). However, to date, no empirical studies have been carried out on the impacts of temperature on park tourism in southern Africa.

\section{Materials and methods Study area}

South Africa has 19 national parks, which are managed by South African National Parks (SANParks), a state-owned parastatal. These parks constitute $52 \%$ of terrestrial protected area in the country and are located throughout South Africa 
(Figure 1). Each park has its own unique climate, topography and water resources, resulting in a diversity of vegetation and species conserved at the national level, and a unique tourist offering at most parks. Because of the large spatial diversity between parks, the projected change in climate for individual parks varies greatly, with some parks expected to experience far larger changes in temperature and precipitation than others (Table 1).

\section{Climate data}

Following Fisichelli et al. (2015), historical monthly occupancy data were matched with gridded historical monthly mean temperature $\left({ }^{\circ} \mathrm{C}\right)$ data obtained from the CRU high-resolution time series version 4.03 (Harris et al. 2020). Climatic Research Unit data are derived by the interpolation of monthly climate anomalies from extensive networks of weather station observations and are globally available at 0.5 decimal degrees $\left(\sim 50 \mathrm{~km}^{2}\right)$ for each month and year of occupancy data $(n=81)$. CRU data were deemed preferable to South African Weather Service (SAWS) data for this study as they are publicly available and free to download, CRU incorporates quality-controlled data from individual stations (including SAWS data) to produce a uniform grid of data points spanning the entire Earth and SAWS data is not available for all of South Africa's national parks and there are considerable gaps in the data and differences in the type of data available at the park level (see Van Wilgen et al. 2016).

Although a concerted effort is being made globally to curb greenhouse gas emissions, up to at least 2014, emissions have been tracking just above the representative concentration pathway (RCP) 8.5 scenario, considered the worst-case scenario by the Intergovernmental Panel on Climate Change (IPCC) (Sanford et al. 2014). Owing to the consensus that the climate change we experience over the next few decades will primarily be caused by past emissions (Glick, Stein \& Edelson 2011), the RCP 8.5 scenario was used in this study.

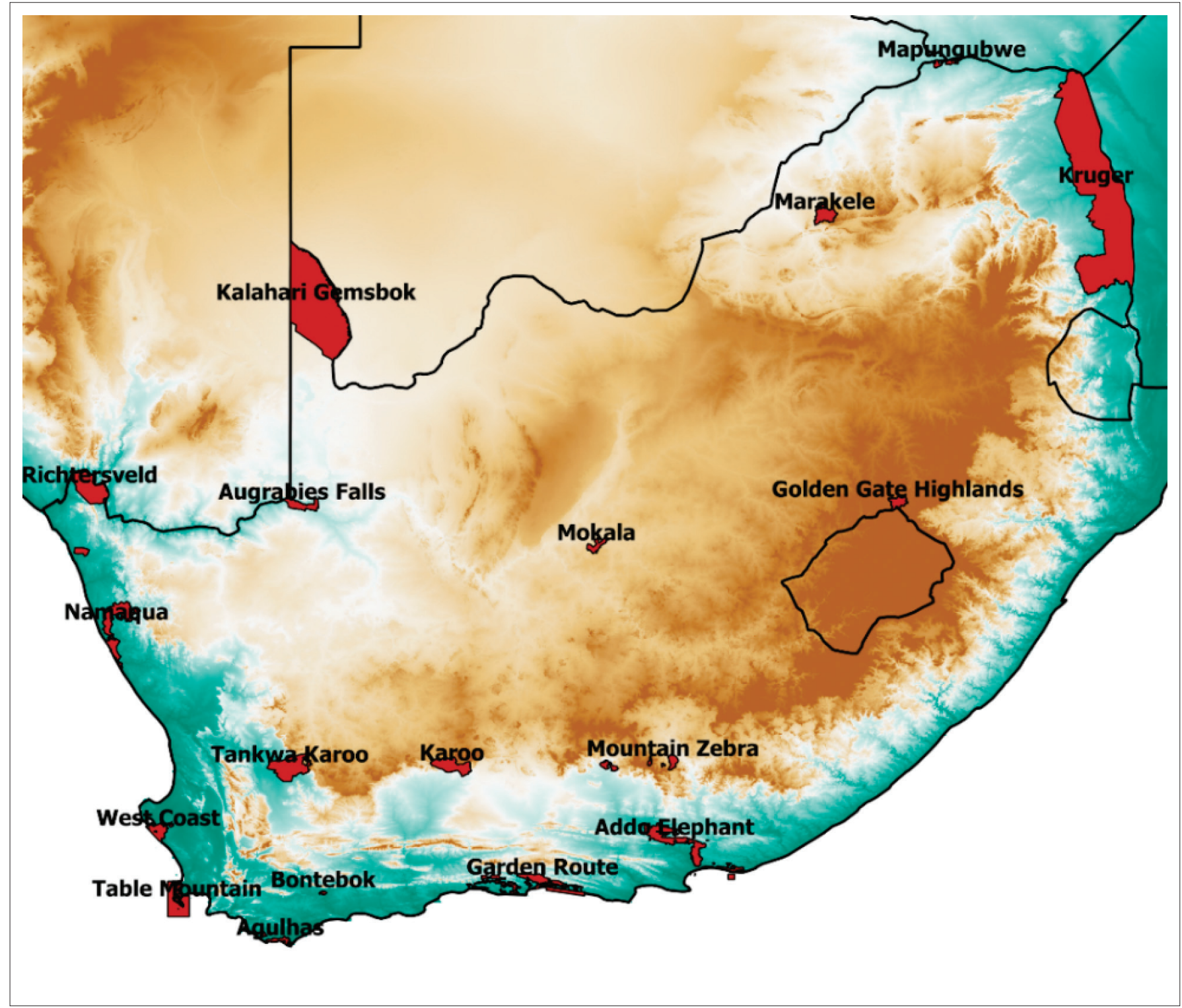

FIGURE 1: Map showing the national parks of South Africa. 
TABLE 1: Projected percentage change in mean annual temperature and total annual precipitation for each park from historic average (1960-1990) to midcentury (2040-2060), by using Coupled Model Inter-Comparison Project data.

\begin{tabular}{lcc}
\hline Park & $\begin{array}{c}\text { \% change in mean annual } \\
\text { temperature }\end{array}$ & $\begin{array}{c}\text { \% change in total annual } \\
\text { rainfall }\end{array}$ \\
\hline Addo Elephant & 10.0 & -6.4 \\
Agulhas & 9.4 & -6.3 \\
Augrabies Falls & 13.5 & -17.7 \\
Bontebok & 9.6 & 37.0 \\
Camdeboo & 13.2 & 1.6 \\
Garden Route & 11.0 & 28.0 \\
Golden Gate & 20.1 & 9.2 \\
Karoo & 14.7 & -6.9 \\
Kgalagadi & 14.3 & -5.5 \\
Kruger & 10.6 & 6.2 \\
Mapungubwe & 11.6 & -0.9 \\
Marakele & 15.0 & -4.0 \\
Mokala & 16.2 & -2.7 \\
Mountain Zebra & 15.8 & 2.7 \\
Namaqua & 10.6 & -9.1 \\
\hline Richtersveld & 12.2 & -0.3 \\
Table Mountain & 9.7 & 32.9 \\
Tankwa Karoo & 12.7 & -29.0 \\
West Coast & 9.3 & -18.0 \\
\hline & &
\end{tabular}

Furthermore, because near-term projections of climate change scenarios tend to have a higher degree of certainty, a relatively short time horizon of mid-century (2040-2060) was used. Apart from the uncertainty inherent in longer time frames, the choice of mid-century limits the magnitude of divergence between the different RCPs.

\section{Statistical analysis}

Monthly occupancy data, spanning the period April 2012 to December 2016, for both accommodation units and campsites were used as the dependent variable in this study $(n=57)$, a proxy for tourism demand. Occupancy levels were chosen instead of total visitor numbers (which includes day visitors) because occupancy is driven largely by tourist perceptions of mean monthly weather for holiday months, and day visitors may time their visits to parks to avoid the hottest or coldest times of the day. Although tourism demand is influenced by a number of factors (Biggs et al. 2014), this article investigates the influence of climate, which was not considered by their study. Relationships between mean monthly occupancy rates, mean monthly temperature and rainfall were investigated at park level and overall. On this basis the more detailed statistical analysis omitted rainfall. This is consistent with the findings of Mathivha et al. (2017) that there was no statistically significant relationship between tourist arrivals and rainfall. Therefore, mean monthly temperature and holiday months were used as explanatory variables, as well as the interaction between the two. In support of the use of temperature, Giddy et al. (2017) found that American tourists most often cited very hot temperatures as negative experiences with weather during their stay in South Africa. The holiday months included the peak tourism months of April, July, September and December, which cover the main school and university holidays. The majority of domestic tourists only have these small windows in which to plan their holiday activities (Amelung et al. 2007) and climate change may make it unbearable to visit certain parks during these months. The remaining 24 months (January 2017 to December 2018) of occupancy data was held back for out-ofsample model evaluation.

Park-specific models were developed to assess the relationship between historical occupancy and climate by using R statistical software (R core team 2014). For each park, OLS regression was used, and three models of increasing complexity were tested to quantify the relationship between occupancy levels and temperature and holiday months: a null model (intercept only); the first-order (linear) polynomial function of temperature and holiday months; and the secondorder (quadratic) polynomial function of temperature and holiday months. Bayesian information criterion (BIC) was used to identify the best model for each park, and the model selections were intuitively assessed to make sure that the signs of the variables were consistent with expectations. The best-fit models were then used to estimate the change in annual occupancy between the baseline period (2012-2016) and the future period (2040-2060). The turning point of the quadratic best-fit functions was calculated by using the formula $b_{1} /-2 b_{2}$.

Park-specific model performance was assessed by using root mean square error (RMSE), an indicator of prediction accuracy. RMSE for each park was calculated for both the estimation period (in-sample; $n=57$ ) and the validation period (out-of-sample; $n=24$ ) by using the following formula:

$\mathrm{RMSE}=\sqrt{ } \frac{1}{n} \sum_{t=1}^{n}\left(\hat{y}_{t}-y_{t}\right)^{2}$

[Eqn 1]

where $\hat{y}_{t}$ and $y_{t}$ are the predicted monthly occupancy and observed monthly occupancy rates, respectively.

Fixed effects and random effects panel regression analysis was also performed to determine if a single model could be fitted to the entire park system. Three separate models were tested: the quadratic function of temperature and holiday months on all 19 parks; the same quadratic function but on only the parks that exhibited a quadratic best-fit model; and the linear function of temperature and holiday months on only the parks that exhibited a linear best-fit model. Lagrange multiplier and $\mathrm{F}$ tests were performed on the three models to determine if there were significant differences between the random effects model and the OLS model and the fixed effects model and the OLS model, respectively. Finally, a Hausman test was performed to determine whether the fixed effects or random effects model should be considered. All models assumed that visitor numbers were minimally constrained by bed capacity, and that installation of visitor facilities responded to demand consistently across all parks.

\section{Ethical consideration}

The authors declare that ethical clearance was not required for the study. 


\section{Results}

\section{Influence of temperature on tourist numbers}

In nearly all cases, mean monthly occupancy rates were strongly related to mean monthly temperatures (Figure 2). Depending on the range of temperatures experienced at each park, the relationships were either positive, negative or an inverse U. However, the relationship to temperature was not consistent across parks. Occupancy rates were also correlated with rainfall, but the $\mathrm{R}^{2}$ value was also lower than for the relationship with temperature in all but four cases. Rainfall was strongly correlated with temperature in all but two parks, either positively in the case of the summer rainfall areas (13 parks) or negatively in the winter rainfall area parks

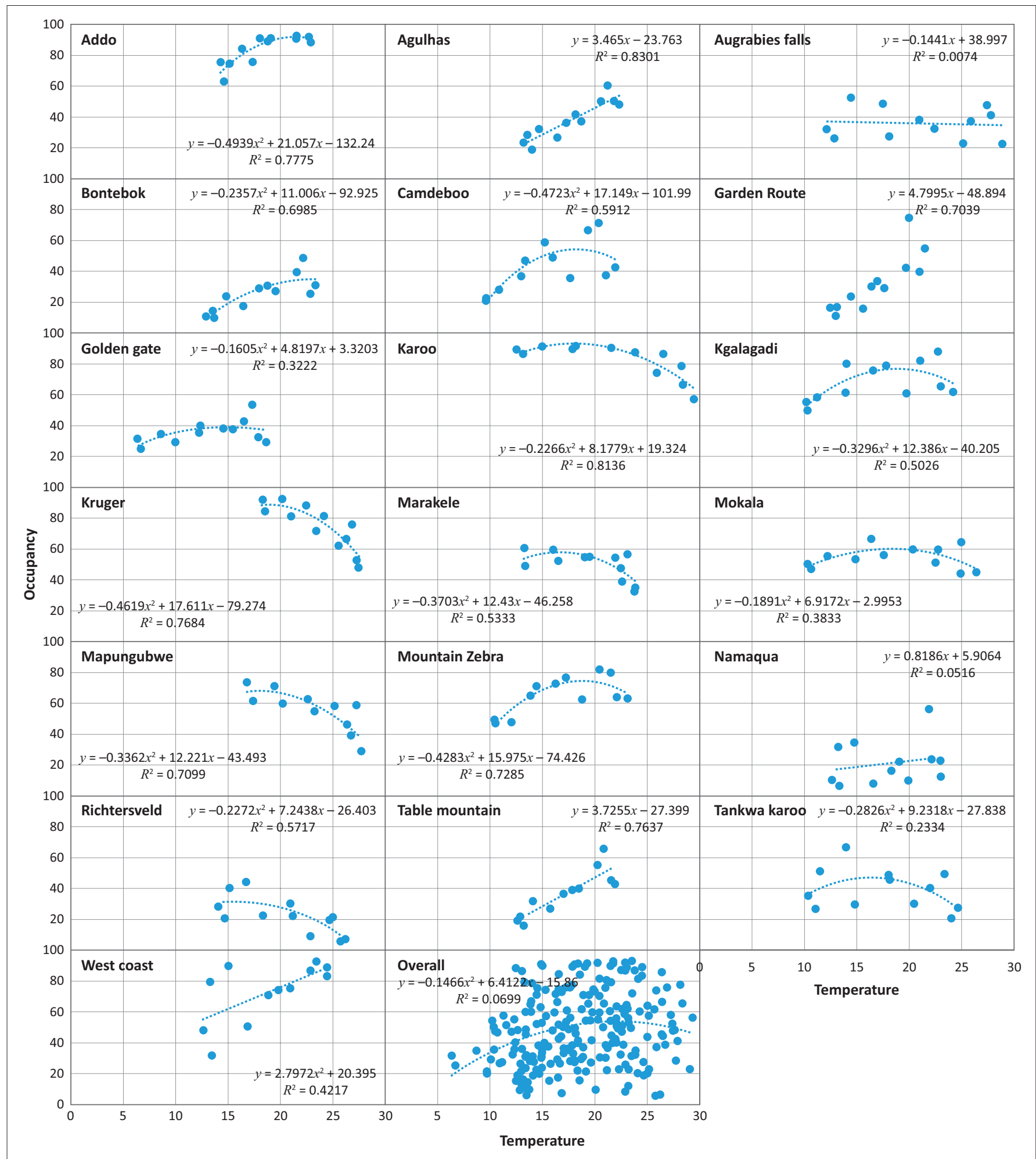

FIGURE 2: Relationship between mean monthly temperature $\left({ }^{\circ} \mathrm{C}\right)$ and mean monthly percentage occupancy rate for each national park and overall. Parks are presented in alphabetical order. 
(Agulhas, Bontebok, Namaqua, Table Mountain, Tankwa Karoo and West Coast national parks). Inclusion of mean monthly rainfall generally made little difference to model fit, and frequently did not have the expected negative sign on the coefficient. Therefore, rainfall was not considered to be an important driver of occupancy rates.

The results of the statistical analysis in combination with other control variables indicated that for 13 of the parks, occupancy and temperature exhibit a significant quadratic relationship, although for six of the parks, occupancy and temperature exhibit a significant linear relationship. Two of the parks (Augrabies Falls and Mokala national parks) had an $R^{2}$ value of less than 0.5 and for Augrabies Falls National Park, which has one of the highest year-round average temperatures, the temperature variables are insignificant (Table 2). The temperature models explained more than 50\% of the variance in historical occupancy for the remaining 17 parks, with 14 parks having more than $60 \%$ of the variance in historical occupancy explained by the models and seven of those parks had more than $70 \%$ of the variance in historical occupancy explained by the models (Table 2).

For the parks exhibiting a quadratic temperature function, the turning point above which occupancy levels decreased ranged from $14.2^{\circ} \mathrm{C}$ for Golden Gate National Park to $25.7^{\circ} \mathrm{C}$ for Bontebok National Park (Table 2). The turning points for these parks were not significantly correlated with the mean annual temperatures of the parks. However, with the exception of Bontebok National Park, the turning points were significantly correlated with mean occupancy level $(n=12$, $\left.R^{2}=0.57, p<0.01\right)$ and maximum occupancy level $\left(R^{2}=0.62\right.$, $p<0.01$ ). Note that mean occupancy level was a logarithmic function of maximum occupancy $(y=36.318 \ln (\mathrm{x})-66.194$,
$R^{2}=0.87$ ), suggesting that parks with the highest occupancy levels were experiencing some level of capacity constraints.

The results of the fixed effects and random effects panel regression analyses of the overall dataset were all highly significant, but explained less of the variance, suggesting that a single model could not capture all the location-specific temperature and tourism demand dynamics (Table 3). For each of the three models tested, both the fixed effects and random effects models were superior to the OLS model (Table 3). In addition, the Hausman test indicated that the random effects models were better than the fixed effects models. For the two quadratic panel regression models

TABLE 3: Results of the fixed effects and random effects panel regressions and the results of the Lagrange Multiplier Test for balanced panels, the F test for individual effects and the Hausman Test.

\begin{tabular}{lccc}
\hline Variable & Model 1 & Model 2 & Model 3 \\
\hline Fixed effects & & & \\
Temp & $9.09 * * *$ & $9.24 * * *$ & $3.13 * * *$ \\
Temp & & \\
Holiday & $-0.23 * * *$ & $-0.25 * * *$ & \\
$R^{2}$ & $8.88 * * *$ & $8.45 * * *$ & $10.87 * * *$ \\
Random effects & $0.31 * * *$ & $0.41 * * *$ & $0.48 * * *$ \\
Intercept & & & \\
Temp & $-37.83 * * *$ & $-27.84 * * *$ & $-19.35 *$ \\
Temp & $9.07 * * *$ & $9.24 * * *$ & $3.14 * * *$ \\
Holiday & $-0.23 * * *$ & $-0.25 * * *$ & \\
$R^{2}$ & $8.89 * * *$ & $8.46 * * *$ & $10.87 * * *$ \\
Tests & $0.3 * * *$ & $0.41 * * *$ & $0.48 * * *$ \\
LM test & & & \\
F test & $125.53 * * *$ & $107.92 * * *$ & $56.42 * * *$ \\
Hausman test & $173.33 * * *$ & $260.72 * * *$ & $125.17 * * *$ \\
\hline
\end{tabular}

Model 1 refers to the quadratic function with all 19 parks; Model 2 to the quadratic function with only the 13 parks that exhibited a quadratic function; and Model 3 to the linear function with only the six parks that exhibited a linear function.

LM, Lagrange multiplier.

$*$, significance $<0.05 ; * *$, significance $<0.01 ; * *$, significance $<0.001$.

TABLE 2: Results of the statistical analysis, indicating the best-fit model for each park. For the parks exhibiting a quadratic function, the temperature turning point is also shown. Significance: $<0.001 * * *,<0.01 * *,<0.05 *$

\begin{tabular}{|c|c|c|c|c|c|c|c|c|}
\hline \multirow[t]{2}{*}{ Park } & \multicolumn{6}{|c|}{ Variables } & \multirow[t]{2}{*}{$R^{2}$} & \multirow{2}{*}{$\begin{array}{l}\text { Temperature } \\
\text { turning point }\end{array}$} \\
\hline & Intercept & Temp & Temp ${ }^{2}$ & Holiday & Holiday*Temp & Holiday*Temp ${ }^{2}$ & & \\
\hline Addo Elephant & $-132.21 * * *$ & $20.39 * * *$ & $-0.46 * * *$ & $30.67 * *$ & $-1.46 * *$ & - & $0.75 * * *$ & 22.03 \\
\hline Agulhas & $-26.43 * * *$ & $3.48 * * *$ & - & $6.89 * *$ & - & - & $0.69 * * *$ & $\mathrm{n} / \mathrm{a}$ \\
\hline Augrabies Falls & $41.2696 * * *$ & -0.3901 & - & -14.1458 & $1.1477 *$ & - & $0.25 * *$ & $n / a$ \\
\hline Bontebok & $-67.67 *$ & $7.92 *$ & -0.15 & - & - & $0.03 * * *$ & $0.72 * * *$ & 25.73 \\
\hline Camdeboo & $-72.86 * * *$ & $12.84 * * *$ & $-0.34 * * *$ & - & - & $0.06 * * *$ & $0.69 * * *$ & 18.69 \\
\hline Golden Gate & -4.84 & $6.02 * *$ & $-0.21 *$ & $45.31 *$ & $-8.48 * *$ & $0.40 * *$ & $0.54 * * *$ & 14.17 \\
\hline Kgalagadi & 9.39 & $9.22 * * *$ & $-0.25 * * *$ & $47.63 *$ & $-5.24 *$ & $0.14 * *$ & $0.82 * * *$ & 18.18 \\
\hline Karoo & -33.48 & $11.20 * * *$ & $-0.30 * * *$ & 2.47 & - & 0.03 & $0.59 * * *$ & 18.76 \\
\hline Kruger & -119.92 & $21.13 * *$ & $-0.54 * * *$ & $324.10 * *$ & $-30.03 * *$ & $0.69 * *$ & $0.79 * * *$ & 19.57 \\
\hline Mapungubwe & $-202.00 * *$ & $26.33 * * *$ & $-0.65 * * *$ & $383.91 * * *$ & $-35.77 * * *$ & $0.82 * * *$ & $0.76 * * *$ & 20.40 \\
\hline Marakele & -77.12 & $15.41 * *$ & $-0.44 * *$ & $159.61 *$ & $-17.74 *$ & $0.49 *$ & $0.52 * * *$ & 17.33 \\
\hline Mokala & 3.56 & $5.77 * * *$ & $-0.16 * * *$ & - & $0.44 * * *$ & - & $0.35 * * *$ & 18.48 \\
\hline Namaqua & -11.54 & $1.33 * * *$ & - & $24.16 * * *$ & - & - & $0.67 * * *$ & $\mathrm{n} / \mathrm{a}$ \\
\hline Richtersveld & -20.51 & $6.05 *$ & $-0.19 * *$ & $9.31 * * *$ & - & - & $0.62 * * *$ & 15.76 \\
\hline Table Mountain & $-32.58 * * *$ & $3.87 * * *$ & - & $8.12 * *$ & - & - & $0.65 * * *$ & $\mathrm{n} / \mathrm{a}$ \\
\hline Tankwa & -13.09 & $6.19 * *$ & $-0.19 * *$ & $20.34 * * *$ & - & - & $0.67 * * *$ & 16.54 \\
\hline West Coast & -15.61 & $4.30 * * *$ & - & $87.41 * * *$ & $-3.58 * * *$ & - & $0.73 * * *$ & $\mathrm{n} / \mathrm{a}$ \\
\hline
\end{tabular}

Note: The asterisk in the headings represent the interaction between the two variables.

$*$, significance $<0.05 ; * *$, significance $<0.01 ; * *$, significance 0.001 .

$\mathrm{n} / \mathrm{a}$, no turning point can be calculated as the relationship is linear; Temp, mean monthly temperature. 
(Model 1 and Model 2), the turning points $\left(19.9^{\circ} \mathrm{C}\right.$ and $18.5^{\circ} \mathrm{C}$, respectively) were close to the mean turning point of the 13 individual park models of $18.8^{\circ} \mathrm{C}$ (Table 3), as well as the overall mean average temperature of the parks of $18.4^{\circ} \mathrm{C}$.

\section{How accurate were the models in predicting occupancy rates}

The RMSE values for the estimation period were all below 10.0, except for West Coast National Park (10.8), which indicates that the model predictions of monthly occupancy rates were out by less than $10 \%$ on average (Table 4 ). The RMSE values for the validation period improved for five of the parks but worsened marginally for the remaining 14 parks, which is to be expected. These results indicate that the models have a less than $10 \%$ error margin for 15 parks, with the remaining four parks having an error margin marginally higher than $10 \%$ (Table 4 ).

\section{How will climate change impact on occupancy based on the empirical models}

The best-fit models were used to predict the change in annual units occupied for all parks except for Augrabies Falls National Park, for which temperature variables were insignificant (Table 4). The results indicate that only six of the parks assessed are expected to experience a decline in annual occupancy, despite 13 parks exhibiting a quadratic best-fit model. The predicted impact of a warmer climate on the total park system is a decline of nearly $4 \%$, largely owing to the predicted decline in annual occupancy for Kruger National Park (6.4\%), which accounts for the lion's share of the national park systems' overnight visitors. The other parks

TABLE 4: Root mean square error for both the estimation and validation periods, and the predicted change in annual units occupied for each park based on the individual best-fit models.

\begin{tabular}{|c|c|c|c|c|c|}
\hline Park & $\begin{array}{l}\text { Estimation } \\
\text { period } \\
\text { RMSE }\end{array}$ & $\begin{array}{l}\text { Validation } \\
\text { period } \\
\text { RMSE }\end{array}$ & $\begin{array}{l}\text { Avg. annual } \\
\text { units occupied } \\
(2012-2016)\end{array}$ & $\begin{array}{l}\text { Model predictions } \\
\text { of annual units } \\
\text { occupied (2050) }\end{array}$ & $\begin{array}{c}\% \\
\text { change }\end{array}$ \\
\hline Addo Elephant & 4.92 & 5.95 & 37295 & 37636 & 0.91 \\
\hline Agulhas & 7.43 & 7.72 & 3471 & 3525 & 1.55 \\
\hline Augrabies Falls $\dagger$ & 9.32 & 7.15 & - & - & - \\
\hline Bontebok & 6.61 & 5.56 & 5241 & 6122 & 16.82 \\
\hline Camdeboo & 9.38 & 9.87 & 2943 & 3340 & 13.47 \\
\hline Garden Route & 8.58 & 9.30 & 55000 & 58067 & 5.58 \\
\hline Golden Gate & 6.04 & 6.27 & 26005 & 27302 & 4.99 \\
\hline Kgalagadi & 4.38 & 7.80 & 53790 & 52492 & -2.41 \\
\hline Karoo & 8.85 & 11.39 & 17199 & 17710 & 2.97 \\
\hline Kruger & 6.36 & 4.95 & 554644 & 518928 & -6.44 \\
\hline Mapungubwe & 7.34 & 8.35 & 8211 & 7411 & -9.74 \\
\hline Marakele & 7.16 & 8.41 & 11082 & 10123 & -8.65 \\
\hline Mokala & 7.86 & 6.16 & 8355 & 8354 & 0.00 \\
\hline Mountain Zebra & 7.55 & 12.87 & 9956 & 9891 & -0.66 \\
\hline Namaqua & 8.45 & 12.94 & 3909 & 4058 & 3.81 \\
\hline Richtersveld & 7.34 & 8.65 & 6082 & 6993 & 14.98 \\
\hline Table Mountain & 9.53 & 9.76 & 3608 & 3712 & 2.88 \\
\hline Tankwa Karoo & 7.75 & 6.90 & 3791 & 3539 & -6.63 \\
\hline West Coast & 10.80 & 14.40 & 534 & 556 & 4.12 \\
\hline Total & - & - & 811116 & 779759 & -3.87 \\
\hline
\end{tabular}

The parks marked with $t$ were excluded from the total values as the models were deemed inadequate at predicting out-of-sample occupancy rates.

Avg, average; RMSE, root mean square error. that contributed to the total park system decline were Kgalagadi National Park (the South African component of the Kgalagadi Trans-frontier Park; 2.4\% decline), Mapungubwe National Park (9.7\%), Marakele National Park (8.7\%), Mountain Zebra National Park (0.7\%) and Tankwa Karoo National Park (6.6\%; Table 4).

\section{Discussion}

If high mean monthly temperatures were a significant deterrent to tourists, then it would be expected that, if all other variables are adequately controlled for, there should be a relatively consistent marginal effect of temperature, and a general threshold mean monthly temperature above which visitation levels are negatively affected. The fixed effects panel data regression, which controlled for time invariant differences between the parks (i.e. a whole suite of park characteristics such as locational and wildlife attributes), confirmed that temperature does have a significant effect on overall occupancy rates. However, this model suggests a turning point temperature of around $18.8^{\circ} \mathrm{C}$. Interestingly, this threshold was close to the overall mean average temperature of the parks of $18.4^{\circ} \mathrm{C}$. This suggests that, after controlling for school holiday periods, visitors prefer to visit parks in reasonably cool-mild temperatures. The slightly lower threshold temperature obtained in the panel data analyses warranted closer inspection of the relationships in individual parks.

The results of the empirical analysis suggest that tourists to South Africa's national parks are sensitive to temperature. For 13 parks $(72 \%)$, the best-fit models conform to the expectation of an inverted U-shape relationship between the expected mean monthly temperature and visitation (RossellóNadal 2014), indicating that above a certain mean monthly temperature threshold, tourism demand decreases. For the five coastal parks, which are in year-round (Garden Route National Park) and winter-rainfall areas (Agulhas, Namaqua, Table Mountain and West Coast national parks), and where mean monthly temperatures are moderated by cool onshore winds, the relationship between temperature and occupancy is positive and linear for the range of mean monthly temperatures experienced up to now. These are not wildlife parks and tend to be more popular in summer when visitors can enjoy beach activities. The linearity of the relationship suggests that mean monthly temperatures have not yet reached the levels above which tourists would be deterred. With the exception of Namaqua National Park, these parks are also all located in close proximity to large urban areas and receive a larger proportion of day visitors than overnight visitors owing to the extensive alternative accommodation available in close proximity. This study has not captured the impact of climate change on day visitors as park accommodation occupancy levels were used. Day visitors would be more likely to have more flexibility in timing their visits to the parks for the most comfortable parts of the day and might therefore exhibit a different relationship. 
The park-specific model predictions of monthly occupancy rates were out by less than $10 \%$ on average during the estimation period for all but West Coast National Park. For five parks (Augrabies Falls, Bontebok, Kruger, Mokala and Tankwa Karoo national parks) RMSE values improved in the validation period compared with the estimation period, with the remaining parks having marginally worse RMSE values during the validation period, an expected result given that the models were generated by minimising the sum of the squares in the difference between the observed and predicted values, by using the estimation period data. In some cases, and West Coast National Park specifically, the RMSE values were worse during the validation period because overnight capacity had been increased during the period, resulting in observed occupancy rates in the validation period being lower than predicted for a number of months as demand lagged in its reaction to a change in supply.

For the parks for which temperature and occupancy exhibit a quadratic relationship, it was possible to calculate the turning points, or the temperature thresholds, above which occupancy rates started to decline. These turning points varied substantially among the individual parks, and many occurred at relatively mild temperatures. It should be noted that these effectively reflect average monthly temperatures, rather than daily temperatures. Thus, a mean monthly temperature of $25^{\circ} \mathrm{C}$ could be interpreted as having a relatively high probability of encountering daily temperatures over $30^{\circ} \mathrm{C}$.

In cases such as Golden Gate National Park, which experiences relatively low year-round temperatures and where occupancy was mostly positively related to temperature, the modelled threshold of $14{ }^{\circ} \mathrm{C}$ seemed too low to be a plausible threshold. Indeed, the direct relationship to temperature was fairly weak in the case of this park, and little seasonality in visitation rates. Given that visitors tend to avoid the coldest months because of the extremely low overnight temperatures, an increase in temperature might start to deter visitors in the hotter months but might also increase occupancy in the lower months. In the case of the hot arid parks (Richtersveld, Tankwa Karoo and Augrabies national parks) which experience very high temperatures and where occupancy was mostly negatively related to temperature, the data and thresholds $\left(15.8{ }^{\circ} \mathrm{C}\right.$ and $16.5^{\circ} \mathrm{C}$ for the first two, and undefined for the third) reflected that the parks are fullest in their cooler but not coldest months. Overall increases in mean monthly temperatures would be expected to lead to overall decreases in visitor bookings but could be averted by increasing the available accommodation so that more people can visit in the coolest months. The other arid zone park, Kgalagadi National Park, experiences slightly more moderate conditions and had a higher turning point of $18.2^{\circ} \mathrm{C}$. This park is most popular in spring and autumn to avoid the extreme cold nights and extreme hot days of winter and summer, respectively.
For the parks in the summer rainfall areas of the savanna biome (the 'bushveld'), temperatures can reach uncomfortable levels in the summer months, which are also the wet months. Wildlife viewing also tends to be better in the dry winter months when there is less foliage and grass, and when animals tend to congregate at watering points. Therefore, it is unsurprising that there is a steeply negative association between occupancy and temperature in Kruger and Mapungubwe national parks. As with the desert parks, higher overall temperatures would be expected to shift demand to the cooler months, leading to reduced numbers unless park capacity is increased.

In Karoo National Park, where visibility is less of a factor, there is less of an association with temperature, apart from a steep drop off in occupancy in the hottest months. In Bontebok National Park and the Eastern Cape parks (Addo, Camdeboo and Mountain Zebra national parks), which experience relatively moderate temperatures and relatively little seasonality in their fynbos, karoo and thicket vegetation cover, visitors tend to increase in warmer months, apart from the very hottest months (Figure 2). Increasing temperatures would be expected to shift demand to cooler months, and this could be better accommodated than in parks with an inverse relationship with temperature. Thus, the impact of a degree rise in temperature would be expected to be lower for these parks than for the bushveld and arid zone parks.

There was also an interesting positive relationship between the turning point threshold and overall occupancy level of parks. Bearing in mind that occupancy levels are not a measure of park popularity per se (which is reflected in bed numbers), higher occupancy levels would be expected to reflect more consistent rates of occupancy throughout the year (such as for Karoo National Park), or periods of the year with very high occupancy (such as the flagship Kruger and Addo Elephant national parks). These parks have more to lose with an increase in temperature by virtue of their already high turning points, which more closely align with comfort levels and the fact that they are likely to be close to their environmental capacity in terms of accommodating visitors.

The results of the empirical analysis are important for exploring and estimating the impact that climate change may have on tourism demand for individual parks and at the park system level, especially if tourism is a major financial contributor to the park system's operational budget as is the case in South Africa (Novellie 2018). Applying climate change predictions for the period 20402060 to these models suggested that the majority of parks in South Africa (61\%) will see an increase in occupancy. This is in line with the explanations above and with other international studies (e.g. Fisichelli et al. 2015; Jones \& Scott 2006). This is largely attributed to these parks moving up the occupancy-temperature curve for most months of the year and these increases in occupancy outweighing the decreases experienced during the hotter months of the year. It must 
be noted that the estimated change is indicative only as, although the extent that future predicted mean monthly temperatures exceed the range of modelled data is marginal for most of the parks, tourism demand may respond differently to these unobserved novel climates at specific locations. For instance, tipping points in temperature may be reached that have not been observed at a specific location in the past, resulting in changes to tourism demand that cannot be modelled. This could well be the case for the coastal parks that currently exhibit a linear relationship between occupancy and temperature but which, under higher predicted future temperatures, may reach a tipping point above which occupancy begins to fall.

Although the impact on the entire park system is negative ( $\sim \%$ decline by 2050 ), if the impact on tourism demand for Kruger National Park was excluded from the analysis, the result would be an overall increase for the park system in the order of $\sim 2 \%$. The projected impact on Kruger National Park is of special concern because the revenue generated by the park helps subsidise the rest of the park system, and a decline in tourism revenue would put the capacity for conservation activities at risk (Novellie 2018). Given the high density of beds in this park, there is little option for increasing capacity to accommodate more tourists in the cooler months without leading to congestion and ecological impacts.

Understanding the potential impact of climate change on tourism demand is important for park planning and management, as it helps to focus adaptation considerations. For example, if a protected area manager were to see that his/ her protected area is vulnerable to a decrease in tourism demand because climate conditions may make it unbearable to visit the park during certain periods of the year, then this should inspire adaptation considerations around how to make it more bearable for tourists, such as installing air conditioning in the accommodation units or installing a swimming pool so tourists can cool off during the hotter times of the day. Dube and Nhamo (2019) found that tourism operators in Kruger National Park are already considering and implementing strategies to deal with the observed changes in tourist preferences and responses to unbearable temperatures, including green building design to ensure guest comfort. Alternatively, considerations around increasing tourism capacity to take advantage of tourists' climate preferences should be explored, with consideration given to congestion and ecological constraints. These results also have important bearings on SANParks' marketing strategy with regard to timing and targeting of directed marketing campaigns to increase occupancy and target groups who are perhaps less sensitive to expected temperatures. Implementing adaptation strategies will place a further burden on constrained national park budgets in South Africa.

Although useful for identifying potential climate change impacts on tourism demand owing to tourists' climate preferences, the empirical models are unable to capture the climate change impact on destination attractions that influence the destination decision of tourists, such as the change in snowfall, hydrology, bleaching of reefs, species and vegetation changes, etc. Furthermore, the empirical models do not consider higher levels of domestic tourism in key origin countries owing to more favourable conditions closer to home (Rosselló \& Santana 2012; Tol \& Walsh 2012) or the rising aversion to long-haul flights. For these reasons, tourism operators should consider both a change in tourism comfort levels and the potential climate impacts on attractions when estimating how climate change may influence tourism demand.

We suggest that further research that extends the analysis to a larger number of parks and broader climatic area, as well as to include visitor surveys, would be useful to further explore the role of variables such as rainfall and accommodation characteristics, as well as to validate the findings on visitor motivations.

\section{Conclusion}

Tourists to South Africa's national parks are sensitive to temperature, but only six of the parks assessed are predicted to experience a decline in occupancy by 2050, as movements up the quadratic temperature curves during the coldest months of the year outweigh movements down the temperature curves during the hottest months of the year. Despite this, the predicted unmitigated impact of climate change on total tourism demand across the national park network is for a $4 \%$ decline, largely owing to the roughly $6.5 \%$ decline for Kruger National Park outweighing the predicted changes for the other 18 parks. These results are of concern given that tourism proceeds generated by Kruger National Park are used to subsidise the operating budgets of the entire park system, which would put the capacity for conservation activities at risk, suggesting that measures to alleviate climate discomfort to tourists should be explored by management.

\section{Acknowledgements}

We are grateful to South African National Parks for provision of tourism statistics, and to two anonymous referees for their inputs on an earlier draft.

\section{Competing interests}

The authors have declared that no competing interests exist.

\section{Authors' contributions}

All authors contributed equally to this work.

\section{Funding information}

This research received no specific grant from any funding agency in the public, commercial or not-for-profit sectors.

\section{Data availability statement}

Data sharing is not applicable to this article as no new data were created or analysed in this study. 


\section{Disclaimer}

The views and opinions expressed in this article are those of the authors and do not necessarily reflect the official policy or position of any affiliated agency of the authors.

\section{References}

Abegg, B. \& Koenig, U., 1997, 'Impacts of climate change on winter tourism in the Swiss Alps', Journal of Sustainable Tourism 5(1), 46-58. https://doi.org/10.1080/ 09669589708667275

Amelung, B. \& Viner, D., 2006, 'Mediterranean tourism: Exploring the future with the tourism climate index', Journal of Sustainainable Tourism 14(4), 349-366. https:// doi.org/10.2167/jost549.0

Amelung, B., Nicholls, S. \& Viner, D., 2007, 'Implications of global climate change for tourism flows and seasonality', Journal of Travel Research 45(3), 285-296. https:// doi.org/10.1177/0047287506295937

Belle, E.M.S., Burgess, N.D., Misrachi, M., Arnell, A., Masumbuko, B., Somda, J. et al., 2016, Climate change impacts on biodiversity and protected areas in West Africa, Summary of the main outputs of the PARCC project, protected areas resilient to climate change in West Africa, p. 62, UNEP-WCMC, Cambridge.

Bigano, A., Hamilton, J. \& Tol, R., 2007, 'The impact of climate change on domestic and international tourism: A simulation study', Integrated Assessment Journal 7(1), 25-49. https://doi.org/10.2139/ssrn.907454

Biggs, D., Swemmer, L., Phillips, G., Stevens, J., Freitag, S. \& Grant, R., 2014, 'The development of a tourism research framework by South African National Parks to inform management', Koedoe 56(2), 1-9. https://doi.org/10.4102/koedoe. v56i2.1164

Chown, S.L., 2010, 'Temporal biodiversity change in transformed landscapes: A southern African perspective', Philosophical Transactions of the Royal Society B Biological Sciences 365(1558), 3729-3742. https://doi.org/10.1098/rstb.2010.0274

Collier, P., Conway, G. \& Venables, T., 2008, 'Climate change and Africa', Oxford Review of Economic Policy 24(2), 337-353. https://doi.org/10.1093/oxrep/grn019

Davis-Reddy, CL. \& Vincent, K., 2017, Climate risk and vulnerability: A handbook for Southern Africa 2nd edn., pp. 202, CSIR, Pretoria.

De Freitas, CR., 2003, 'Tourism climatology: Evaluating environmental information for decision making and business planning in the recreation and tourism sector' International Journal of Biometeorology 48, 45-54. https://doi.org/10.1007/ s00484-003-0177-z

Dube, K. \& Nhamo, G., 2018, 'Climate variability change and potential impacts on tourism: Evidence from the Zambian side of the Victoria Falls', Environmental Science \& Policy 84, 113-123. https://doi.org/10.1016/j.envsci.2018.03.009

Dube, K. \& Nhamo, G., 2019, 'Climate change and potential impacts on tourism: Evidence from the Zimbabwean side of the Victoria Falls', Environmental Develpoment and Sustainability 21(4), 2025-2041. https://doi.org/10.1007/ Develpoment and

Dube, K. \& Nhamo, G., 2020, 'Evidence and impact of climate change on South African national parks. Potential implications for tourism in the Kruger National Park', national parks. Potential implications for tourism in the Kruger National Park,
Environmental Development, 33, 100485. https://doi.org/10.1016/j.envdev. Environmental

Dube, K., Mearns, K., Mini, S. \& Chapungu, L., 2018, 'Tourists' knowledge and perceptions on the impact of climate change on tourism in Okavango Delta, Botswana', African Journal of Hospitality, Tourism and Leisure 7(4), 1-18.

Dunlop, M. \& Brown, P., 2008, Implications of climate change for Australia's national reserve system: A preliminary assessment, Report to the Department of Climate Change, and the Department of the Environment, Water, Heritage and the Arts by CSIRO Sustainable Ecosystems, p. 155, CSIRO Australia, Canberra.

Fisichelli, N.A., Schuurman, G.W., Monahan, W.B. \& Ziesler, P.S., 2015, 'Protected area tourism in a changing climate: Will visitation at US national parks warm up or overheat?', PLoS One 10(6), e0128226. https://doi.org/10.1371/journal.pone. 0128226

Fitchett, J.M., Robinson, D. \& Hoogendoorn, G., 2017, 'Climate suitability for tourism in South Africa', Journal of Sustainable Tourism 25(6), 851-867. https://doi.org/1 0.1080/09669582.2016.1251933

Giddy, J.K., Fitchett, J.M. \& Hoogendoorn, G., 2017, 'Insight into American tourists' experiences with weather in South Africa', Bulletin of Geography, Socio-economic Series 38(38), 57-72. https://doi.org/10.1515/bog-2017-0034

Glick, P. Stein, B.A. \& Edelson, N.A., 2011, Scanning the conservation horizon: A guide to climate change vulnerability assessment, p. 176, National Wildlife Federation, Washington, DC.

Hamilton, J.M., Maddison, D.J. \& Tol, R.S., 2005, 'Effects of climate change on international tourism', Climate Research 29(3), 245-254. https://doi.org/10.3354/ cr029245

Harris, I., Osborn, T.J., Jones, P. \& Lister, D., 2020, 'Version 4 of the CRU TS monthly high-resolution gridded multivariate climate dataset', Scientific Data 7(1), 1-18. https://doi.org/10.1038/s41597-020-0453-3

Hoogendoorn, G. \& Rogerson, C.M., 2015, 'Tourism geography in the global South: New South African perspectives', South African Geographical Journal 97(2), 101-110. https://doi.org/10.1080/03736245.2015.1034574

Jones, B. \& Scott, D.J., 2006, 'Climate change, seasonality and visitation to Canada's national parks', Journal of Recreation Administration 24(2), 42-62.
Koenig, N. \& Bischoff, E.E., 2004, 'Seasonality research: The state of the art', Working paper 2004/3, European Business Management School, University of Wales, Swansea, viewed 21 August 2005, from http://www.swan.ac.uk/ebms/research/ Swansea, viewed 21 August 2005, from http://w
working\%20papers/EBMS\%202004\%203.pdf.

Kozak, M., 2002, 'Comparative analysis of tourist motivations by nationality and destinations', Tourism Management 23(3), 207-20. https://doi.org/10.1016/ S0261-5177(01)00090-5

Lemieux, C.J., Beechey, T.J., Scott, D.J. \& Gray, P.A., 2010, Protected areas and climate change in Canada: Challenges and opportunities for adaptation, Canadian Council on Ecological Areas (CCEA) Occasional Paper No. 19, pp. xii + 170, CCEA Secretariat, Ottawa, Ontario.

Lin, T.P. \& Matzarakis, A., 2008, 'Tourism climate and thermal comfort in Sun Moon Lake, Taiwan', International Journal of Biometeorology 52(4), 281-290. https:// doi.org/10.1007/s00484-007-0122-7

Lise, W. \& Tol, R.S.J., 2002, 'Impact of climate on tourist demand', Climatic Change 55(4), 429-449. https://doi.org/10.1023/A:1020728021446

MacFadyen, S., Hui, C., Verburg, P.H. \& Van Teeffelen, A.J., 2019, 'Spatiotempora distribution dynamics of elephants in response to density, rainfall, rivers and fire in Kruger National Park, South Africa', Diversity and Distribution 6(25), 880-894. https://doi.org/10.1111/ddi.12907

Maddison, D., 2001, 'In search of warmer climates? The impact of climate change on flows of British tourist', Climatic Change 49, 193e208. https://doi.org/10.1023/ A:1010742511380

Markham, A., Osipova, E., Lafrenz Samuels, K. \& Caldas, A., 2016, World heritage and tourism in a changing climate, United Nations Environment Programme, Nairobi, and United Nations Educational, Scientific and Cultural Organization, Paris, pp. 18-28.

Mathivha, F.I., Tshipala, N.N. \& Nkuna, Z., 2017, 'The relationship between drought and tourist arrivals: A case study of Kruger National Park, South Africa', Jàmbá Journal of Disaster Risk Studies 9(1), 1-8. https://doi.org/10.4102/jamba.v9i1.471

Mieczkowski, Z., 1985, 'The tourism climatic index: a method of evaluating world climates for tourism', Canadian Geographer/Le Géographe Canadien 29(3), 220-233. https://doi.org/10.1111/j.1541-0064.1985.tb00365.x

Moore, W.R., 2010, 'The impact of climate change on Caribbean tourism demand', Current Issues in Tourism 13(5), 495-505. https://doi.org/10.1080/13683500 903576045

Mushawemhuka, W., Rogerson, J.M. \& Saarinen, J., 2018, 'Nature-based tourism operators' perceptions and adaptation to climate change in Hwange National Park, Zimbabwe', Bulletin of Geography Socio-economic Series 42(42), 15-127. https://doi.org/10.2478/bog-2018-0034

Novellie, P.A., 2018, 'Review of National Park science: A century of research in South Africa by Jane Carruthers', Koedoe 60(1), a1550. https://doi.org/10.4102/koedoe. v60i1.1550

Pandy, W.R., 2017, 'Tourism enterprises and climate change: Some research imperatives', African Journal of Hospitality, Tourism and Leisure 6(4), 1-18.

Pandy, W.R. \& Rogerson, C.M., 2018, 'Tourism and climate change: Stakeholder perceptions of at risk tourism segments in South Africa', Euro Economica 37(2), 104-118.

Perch-Nielsen, S.L., Amelung, B. \& Knutti, R., 2010, 'Future climate resources for tourism in Europe based on the daily Tourism Climatic Index', Climatic Change 103(3-4), 363-381. https://doi.org/10.1007/s10584-009-9772-2

Perry, A., 2006, 'Will predicted climate change compromise the sustainability of Mediterranean tourism?', Journal of Sustainainable Tourism 14(4), 367-375. https://doi.org/10.2167/jost545.0

Pike, S., 2002, 'Destination image analysis - A review of 142 papers from 1973 to 2000', Tourism Management 23(5), 541-549. https://doi.org/10.1016/s0261 5177(02)00005-5

Preston-Whyte, R.A. \& Watson, H.K., 2005, 'Nature tourism and climatic change in Southern Africa', in C.M. Hall \& J. Higham (eds.), Tourism, recreation and climate change, pp. 130-142, Channelview, Bristol.

$\mathrm{R}$ Core Team, 2014, R: A language and environment for statistical computing, $\mathrm{R}$ Foundation for Statistical Computing, $R$ package version $1.1-7$, viewed from http://CRAN.R-project.org/package=Ime4.

Rogerson, C.M., 2016, 'Climate change, tourism and local economic development in South Africa', Local Economy 31(1-2), 322-331. https://doi.org/10.1177/ 0269094215624354

Roshan, G., Yousefi, R. \& Fitchett, J.M., 2015, 'Long-term trends in tourism climate index scores for 40 stations across Iran: The role of climate change and influence on tourism sustainability', International Journal of Biometeorology 60, 33-52. https://doi.org/10.1007/s00484-015-1003-0

Rosselló, J. \& Santana, M., 2012, Climate change and global international tourism: An evaluation for different scenarios, Working paper: Departament d'Economia Aplicada, Universitat de les Illes Balears, Palma, p. 16

Rosselló-Nadal, J., 2014, 'How to evaluate the effects of climate change on tourism', Tourism Management 42, 334-340. https://doi.org/10.1016/j.tourman.2013. 11.006

Sanford, T., Frumhoff, P.C., Luers, A. \& Gulledge, J., 2014, 'The climate policy narrative for a dangerously warming world', Nature Climate Change 4(3), 164-166. https:// doi.org/10.1038/nclimate2148

Scott, D. \& McBoyle, G., 2001, 'Using a 'tourism climate index' to examine the implications of climate change for climate as a tourism resource', First International Workshop on Climate, Tourism and Recreation, pp. 69-88, International Society of Biometeorology, Porto Carras. 
Scott, D., Gossling, S. \& Freitas, C.R., 2007, 'Climate preferences for tourism: An exploratory tri-nation comparison', in A. Matzarakis, C.R. De Freitas \& D. Scott Tourism and Recreation, Freiburg.

Scott, D., Gössling, S. \& Hall, C.M., 2012, 'International tourism and climate change', Wiley Interdisciplinary Reviews: Climate Change 3(3), 213-232. https://doi. org/10.1002/wcc.165

Scott, D., McBoyle, G., Minogue, A. \& Mills, B., 2006, 'Climate change and the sustainability of ski-based tourism in eastern North America: A reassessment', Journal of Sustainable Tourism 14(4), 376-398. https://doi.org/10.2167/jost550.0

Scott, D., Rutty, M., Amelung, B. \& Tang, M., 2016, 'An inter-comparison of the holiday climate index $(\mathrm{HCl})$ and the tourism climate index (TCI) in Europe', Atmosphere 7(6), 80. https://doi.org/10.3390/atmos7060080

Smith, T. \& Fitchett, J.M., 2020, 'Drought challenges for nature tourism in the Sabi Sands Game Reserve in the eastern region of South Africa', African Journal of Range \& Forage Science 37(1), 107-117. https://doi.org/10.2989/10220119.2019.1700162
Steyn, J.N. \& Spencer, J.P., 2012, 'Climate change and tourism: Implications for South Africa', African Journal for Physical, Health Education, Recreation and Dance 18(1), 1-19.

Sutherland, K., Ndlovu, M. \& Pérez-Rodríguez, A., 2018, 'Use of artificial waterholes by animals in the southern region of the Kruger National Park, South Africa', South African Journal of Wildlife Research 48(2), 023003. https://doi.org/10.3957/ 056.048.023003

Tol, R.S.J. \& Walsh, S., 2012, 'Climate change and tourism in the Arctic circle', Working paper series 5212, Department of Economics, University of Sussex Business School, Falmer, viewed 10 July 2019, from https://ideas.repec.org/p/sus/susewp/5212.html.

Van Der Merwe, P. \& Saayman, M., 2008, 'Travel motivations of tourists visiting Kruger National Park', Koedoe 50(1), 54-159. https://doi.org/10.4102/koedoe.v50i1.140

Van Wilgen, N.J., Goodall, V., Holness, S., Chown, S.L. \& McGeoch, M.A., 2016, 'Rising temperatures and changing rainfall patterns in South Africa's national parks', International Journal of Climatology, 36(2), 706-721. https://doi.org/10.1002/ joc. 4377 